\title{
COMMUNITY BASED TOURISM (CBT) SEBAGAI STRATEGI PENGEMBANGAN PARIWISATA BERKELANJUTAN DI DTW CEKING DESA PEKRAMAN TEGALLALANG
}

\section{COMMUNITY BASED TOURISM (CBT) AS A SUSTAINABLE TOURISM DEVELOPMENT STRATEGY IN CEKING DTW, TEGALLANTANG VILLAGE}

\author{
Nyoman Surya Wijaya, dan I Wayan Eka Sudarmawan \\ Sekolah Tinggi Pariwisata Bali Internasional \\ surya.wijaya@stpbi.ac.id
}

\begin{abstract}
Research on Community based tourism as a sustainable tourism development strategy in DTW "Ceking" Pekraman Tegallalang village is done with the aim to study Community Based Tourism (CBT) as a tourism development strategy In DTW Ceking village Pekraman Tegallalang and analyzed the development strategy of CBT in DTW Ceking village Pekraman Tegallalang so that it can be sustainable. Using a research approach with a qualitative and quantitative method (mix method), accompanied by a survey method that will help to get a thorough picture covering physical condition, state of tourism and social situation and Culture at DTW Ceking Village Pekraman Tegallalang. So it is reviewed based on the problem, then research is a description of tourism phenomenon and its relation to socio-cultural life as well as the environment, by taking the research site DTW Ceking village Pekraman Tegallalang in Kecamatan Tegallalang, Gianyar Regency, Bali Province, Tepatnya reside in the Village Tegallalang, Gianyar. Obyek ini berbatasan directly with the Pekraman kedisan. Data used is qualitative and quantitative data and will be obtained conclusions that are "grounded". The findings of the research with certainty that is the form of Community Based Tourism as a sustainable tourism development strategy in DTW Ceking village Pekraman Tegallalang, Gianyar.
\end{abstract}

Keywords: Community Based Tourism (CBT), DTW "Ceking" Desa Pekraman Tegallalang, Pariwisata Berkelanjutan.

\begin{abstract}
ABSTRAK
Penelitian tentang pariwisata berbasis masyarakat sebagai strategi pengembangan pariwisata berkelanjutan di DTW "Ceking" Desa Pekraman Tegallalang dilakukan dengan tujuan untuk mempelajari Community Based Tourism (CBT) sebagai strategi pengembangan pariwisata di DTW Ceking, desa Pekraman Tegallalang dan menganalisis strategi pengembangan CBT di DTW Ceking desa Pekraman Tegallalang sehingga bisa berkelanjutan. Penelitian ini menggunakan pendekatan dengan metode kualitatif dan kuantitatif (metode campuran), disertai dengan metode survei yang akan membantu untuk mendapatkan gambaran menyeluruh yang mencakup kondisi fisik, keadaan pariwisata dan situasi sosial dan Budaya di DTW Ceking Desa Pekraman Tegallalang. Jadi ditinjau
\end{abstract}


berdasarkan masalah, maka penelitian merupakan deskripsi dari fenomena pariwisata dan hubungannya dengan kehidupan sosial budaya serta lingkungan, dengan mengambil lokasi penelitian DTW Ceking desa Pekraman Tegallalang di Kecamatan Tegallalang, Kabupaten Gianyar, Provinsi Bali , Tepatnya berada di Desa Tegallalang, Gianyar. Obyek ini berbatasan langsung dengan Desa Pekraman Kedisan. Data yang digunakan adalah data kualitatif dan kuantitatif dan diperoleh kesimpulan yang "membumi". Temuan penelitian dengan pasti yaitu bentuk Community Based Tourism sebagai strategi pengembangan pariwisata berkelanjutan di DTW Ceking desa Pekraman Tegallalang, Gianyar.

Kata kunci: Wisata Berbasis Masyarakat, DTW “Ceking” Desa Pekraman Tegallalang, Pariwisata Berkelanjutan.

\section{PENDAHULUAN}

Badan Pusat Statistik (BPS) Bali mencatat bahwa Bali menerima kunjungan wisatawan mancanegara 4,92 juta orang selama tahun 2016. Jumlah tersebut meningkat 23,14 persen dibanding tahun sebelumnya yang tercatat 4,001 juta orang. Kedatangan wisatawan tersebut langsung dari negaranya dengan menggunakan pesawat udara melalui Bandara Ngurah Rai sebanyak 4,85 juta orang dan sisanya 75.303 orang melalui pelabuhan laut (BPS Provinsi Bali 2017). Ceking merupakan salah satu Daerah Tujuan Wisata ( DTW) di Bali, tepatnya terletak di Kabupaten Gianyar, Desa Pekraman Tegallalangyang. Ceking adalah andalan DTW bagi Kabupaten Gianyar disamping kawasan wisata Ubud. Dan secara kebetulan bahwa DTW Ceking berdampingan dengan kawasan wisata Ubud. Ceking dengan potensi alam persawahan yang berundak-undak dengan latar belakang pepohonan rindang memberikan suatu nuansa alam yang berbeda dengan perpaduan antar sistem pertanian tradisional masyarakat Bali (subak), sawah terasering, bentang alam yang masih terjaga, serta seni dan budaya yang dimiliki masyarakat sekitar kawasan. Kawasan Ceking yang sudah terbangun dan pariwisatanya yang sudah berkembang sangat perlu dijaga kelestariannya mengingat banyaknya fasilitas yang dibangun secara sembarangan, dan tidak mempedulikan lingkungan dan kondisi sekitarnya. Salah satu konsep yang menjelaskan peranan masyarakat dalam pembangunan pariwisata berkelanjutan adalah Community Based Tourism (CBT). Konsep ini menempatkan masyarakat sebagai pelaku utama melalui pemberdayaan masyarakat dalam berbagai kegiatan pariwisata, sehingga kemanfaatan kepariwisataan sebesar-besarnya diperuntukkan bagi masyarakat. Sasaran utama pengembangan kepariwisataan haruslah meningkatkan kesejahteraan masyarakat (setempat).

Salah satu konsep yang menjelaskan peranan masyarakat dalam pembangunan pariwisata berkelanjutan adalah Community Based Tourism (CBT). Konsep ini menempatkan masyarakat sebagai pelaku utama melalui pemberdayaan masyarakat dalam berbagai kegiatan pariwisata, sehingga kemanfaatan kepariwisataan sebesar-besarnya diperuntukkan bagi masyarakat. Sasaran utama pengembangan kepariwisataan haruslah meningkatkan kesejahteraan masyarakat (setempat). Selain itu yang tidak kalah pentingnya adalah memberi pengertian kepada masyarakat bahwa pengembangan suatu kawasan tidak dapat dilakukan hanya oleh pihak pemerintah dan pengusaha pariwisata atau investor, dan juga tidak bisa dilakukan seketika tetapi perlu tahap-tahap perkembangan tertentu. 
Berdasarkan gambaran sebagaimana telah diuraikan pada latar belakang masalah dan dilandasi oleh pemikiran teoritis serta empirik, maka dapat diajukan pokok permasalahan dalam penelitian ini adalah, bagaimanakah strategi pengembangan CBT di Desa Pekraman Tegallalang sehingga dapat berkelanjutan?

Urgensi dari penelitian ini adalah Daerah Tujuan Wisata (DTW) Ceking yang letaknya berdampingan kawasan wisata Ubud, merupakan kawasan wisata dengan potensi alam persawahan yang berundak-undak dengan latar belakang pepohonan yang rindang, dan dipadu dengan sistem pertanian tradisional masyarakat Bali ( subak), sawah terasering, bentang alam yang masih terjaga serta seni budaya yang beraneka ragam, merupakan suatu nuansa alam yang sangat mempesona dan sangat penting dijaga kelestariannya, serta harus dikembangkan secara berkelanjutan. Konsep ini menempatkan masyarakat sebagai pelaku utama melalui pemberdayaan masyarakat dalam berbagai kegiatan pariwisata, sehingga kemanfaatan kepariwisataan sebesar-besarnya diperuntukkan bagi masyarakat. Sasaran utama pengembangan kepariwisataan haruslah meningkatkan kesejahteraan masyarakat (setempat). Namun perkembangan suatu kawasan wisata selalu akan memiliki dampak negatif yang disumbangkan oleh kegiatan pariwisata tersebut termasuk perkembangan kawasan wisata "Ceking" di Desa Pekraman Tegallalang tentunya tidak dapat dielakkan, seperti: pencemaran lingkungan (udara, sampah plastik, air, tanah, suara), lunturnya nilai-nilai luhur warisan budaya dan munculnya masalah sosial (judi, minuman keras, pelacuran). Dengan mengamati dan mencermati fenomena-fenomena yang timbul, maka muncul kekhawatiran akan hancurnya pariwisata "Ceking" di wilayah Desa Pekraman Tegallalang, jika dampak negatif yang timbul tidak Dalam upaya meminimalisasi berbagai dampak negatif dan mengoptimalkan dampak positif pariwisata lahirlah pemikiran untuk mengembangkan pariwisata dengan konsep yang mengarah pada keberlanjutan serta kelestarian ekosistem lingkungan dengan tetap memperhatikan kondisi sosial budaya masyarakat Desa Pekraman Tegallalang agar tetap dipertahankan dan dapat dinikmati oleh generasi yang akan datang. Sedangkan urgensi dari penelitian ini adalah Konsep strategi pengembangan CBT di DTW Ceking ,Desa Pekraman Tegallalang sehingga dapat berkelanjutan, serta percepatan studi mahasiswa terkait dengan pengembangan riset (D4 dan S1)

\section{TINJAUAN PUSTAKA}

\section{A. Teori Community Based Tourism}

Konsep CBT muncul pertama kali sekitar tahun 1970-an akibat adanya kritikan atas dampak negatif yang ditimbulkan oleh mass tourism. Kemudian mendapatkan perhatian lebih pada tahun 2000, dimana Bank Dunia (World Bank) mulai memikirkan bagaimana caranya menanggulangi masalah kemiskinan melalui sektor pariwisata yang kemudian dikenal dengan "community-based tourism" (CBT). Selanjutnya diidentifikasi adanya tiga kegiatan pariwisata yang dapat mendukung konsep CBT yakni adventure travel, cultural travel dan ecotourism. Dibahas pula kaitannya dengan akomodasi yang dimiliki oleh masyarakat atau disebut small family-owned hotels yang biasanya berkaitan erat dengan tiga jenis kegiatan tersebut. Bank Dunia yakin bahwa peningkatan wisata adventure, ecology dan budaya akan mampu meningkatkan pendapatan masyarakat setempat dan 
sekitarnya sekaligus memelihara budaya, kesenian dan cara hidup masyarakat di sekitarnya.

CBT melibatkan pula masyarakat dalam proses pembuatan keputusan, dan dalam perolehan bagian pendapatan terbesar secara langsung dari kehadiran para wisatawan, sehingga dengan demikian CBT akan dapat menciptakan kesempatan kerja, mengurangi kemiskinan dan membawa dampak positif terhadap pelestarian lingkungan dan budaya asli setempat yang pada akhirnya diharapkan akan mampu menumbuhkan jati diri dan rasa bangga dari penduduk setempat yang tumbuh akibat peningkatan kegiatan pariwisata. Jadi sesungguhnya CBT adalah konsep ekonomi kerakyatan di sektor riil, yang langsung dilaksanakan oleh masyarakat dan hasilnyapun langsung dinikmati oleh mereka.

Rest (1997) dalam bukunya menyebutkan bahwa CBT adalah wisata yang mengetengahkan lingkungan, sosial masyarakat, dan kesinambungan budaya dalam satu fokus pengembangan. CBT dikelola dan dimiliki dari dan oleh masyarakat, dengan tujuan memberikan pengetahuan kapada para wisatawan tentang bagaimana kearifan lokal dan kehidupan yang dilakukan sehari-hari di komunitas tersebut. Rest, selanjutnya menyatakan :

"CBT is tourism that takes environmental, social, and cultural sustainability into account. It is managed and owned by the community, for the community, with the purpose of enabling visitors to increase their awareness and learn about the community and lokal ways of life".

Suansri (2003) mendefinisikan CBT sebagai pariwisata yang memperhitungkan aspek keberlanjutan lingkungan, sosial dan budaya. CBT merupakan alat pembangunan komunitas dan konservasi lingkungan. Atau dengan kata lain CBT merupakan alat untuk mewujudkan pembangunan pariwisata yang berkelanjutan. Ciri-ciri khusus dari Community Based Tourism (Timothy, 1999: 373) adalah berkaitan dengan manfaat yang diperoleh dan adanya upaya perencanaan pendampingan yang membela masyarakat lokal serta lain kelompok memiliki ketertarikan/minat, yang memberi control lebih besar dalam proses sosial untuk mewujudkan kesejahteraan. (Murphy, 1985) menekankan strategi yang terfokus pada identifikasi tujuan masyarakat tuan rumah dan keinginan serta kemampuan mereka menyerap manfaat pariwisata. Menurut Murphy setiap masyarakat harus didorong untuk mengidentifikasi tujuannya sendiri dan mengarahkan pariwisata untuk meningkatkan kebutuhan masyarakat lokal.

CBT tidak berada pada tataran bagaimana pariwisata dapat memberikan manfaat yang lebih bagi komunitas, tetapi lebih pada bagaimana pariwisata dapat berkontribusi pada proses pembangunan masyarakat. CBT bukanlah bisnis wisata yang sederhana dan merujuk pada pemaksimalan profit untuk para investor. CBT lebih memfokuskan pada dampak pariwisata itu sendiri terhadap masyarakat (komunitas) dan sumberdaya lingkungan. CBT muncul dari suatu strategi pembangunan masyarakat, menggunakan wisata sebagai alat untuk memperkuat kemampuan organisasi masyarakat mengatur sumber daya wisata yang ada melaui partisipasi langsung masyarakat tersebut. Berikut adalah prinsip-prinsip dalam CBT :

a. Mengakui, mendukung dan mengembangkan kepemilikan komunitas dalam industri pariwisata. 
b. Mengikutsertakan anggota komunitas dalam memulai setiap aspek

c. Mengembangkan kebanggaan komunitas

d. Mengembangkan kualitas hidup komunitas.

e. Menjamin keberlanjutan lingkungan.

f. Mempertahankan keunikan karakter dan budaya di area lokal

g. Membantu berkembangnya pembelajaran tentang pertukaran budaya pada komunitas

h. Menghargai perbedaan budaya dan martabat manusia

i. Mendistribusikan keuntungan secara adil pada anggota komunitas.

j. Berperan dalam menentukan prosentase pendapatan.

Poin-poin yang merupakan aspek utama pengembangan CBT berupa 5 dimensi, yaitu:

a. Dimensi ekonomi, dengan indikator berupa adanya dana untuk pengembangan komunitas, terciptanya lapangan pekerjaan di sektor pariwisata, timbulnya pendapatan masyarakat lokal dari sektor pariwisata

b. Dimensi sosial dengan indikator meningkatnya kualitas hidup, peningkatan kebanggaan komunitas, pembagian peran yang adil antara laki -laki perempuan, generasi muda dan tua, membangun penguatan organisasi komunitas.

c. Dimensi budaya dengan indikator berupa mendorong masyarakat untuk menghormati budaya yang berbeda, membantu berkembangnya pertukaran budaya, budaya pembangunan melekat erat dalam budaya lokal.

d. Dimensi lingkungan, dengan indikator mempelajari carrying capacity area, mengatur pembuangan sampah, meningkatkan kepedulian akan perlunya konservasi.

e. Dimesi politik, dengan indikator: meningkatkan partisipasi dari penduduk lokal, peningkatan kekuasaan komunitas yang lebih luas, menjamin hak-hak dalam pengelolaan SDA.

\section{B. Teori Pembangunan Berkelanjutan}

Pembangunan pariwisata berkelanjutan menurut The World Conservation Union (WCU) adalah proses pembangunan suatu tempat atau daerah tanpa mengurangi nilai guna dari sumber daya yang sudah ada. Secara umum hal ini dapat dicapai dengan pengawasan dan pemeliharaan terhadap sumber-sumber daya yang sekarang ada, agar dapat dinikmati untuk masa yang akan datang. Pembangunan kepariwisataan bertahan lama menghubungkan wisatawan sebagai penyokong dana terhadap fasilitas pariwisata dengan pemeliharaan lingkungan. Menurut World Commicion on Environment and Development konsep pariwisata berkelanjutan adalah bagian dari pembangunan berkelanjutan yang memperhatikan kebutuhan saat ini dengan mempertimbangkan kebutuhan (hidup) generasi penerus di waktu yang akan datang. Arti lebih jauh, dalam pembangunan hendaknya jangan menghabiskan atau menguras sumber daya pariwisata untuk jangka pendek, tetapi harus memperhatikan kelanjutan pembangunan pariwisata jangka panjang di waktu yang akan datang.

Tourism Stream, action strategy yang diambil dari Globe'90 conference Vancouver, Canada (J. Swarbroke, 1998) menyatakan bahwa, kepariwisataan berkelanjutan (sustainable tourism) didefinisikan sebagai bentuk dari 
pengembangan ekonomi yang dirancang untuk meningkatkan kualitas hidup dari masyarakat sekitar, memberikan image yang positif bagi wisatawan, pemeliharaan kualitas lingkungan hidup yang tergantung dari masyarakat sekitar dan wisatawan itu sendiri. Daya dukung (carring capacity) adalah kunci bagi pengembangan kepariwisataan bertahan lama (sustainable tourism). Konsep ini mengacu pada penggunaan secara maksimal dari suatu daya tarik wisata tanpa mengakibatkan kerusakan sumber-sumber yang ada, yang dapat mengurangi kepuasan turis atau menambah masalah sosial dan ekonomi bagi masyarakat sekitar. Prinsip lain dari sustainable tourism menurut Kingdoms Department of the Environment (Magdalena, 2002) yang juga kurang lebih sama dengan konsep-konsep yang sudah ditulis sebelumnya antara lain :

a. Lingkungan hidup mempunyai nilai yang tersirat sebagai asset dari pariwisata, yang keberadaannya harus dipertimbangkan untuk jangka panjang.

b. Kepariwisataan harus dapat dikenalkan sebagai aktivitas yang positif yang dapat memberikan keuntungan yang potensial kepada masyarakat di tempat-tempat lain disekitarnya.

c. Hubungan antara pariwisata dan lingkungan harus dikelola sehingga lingkungan hidup dapat bertahan untuk jangka panjang dan kegiatan pariwisata tidak boleh membawa dampak yang tidak diharapkan.

d. Kegiatan kepariwisataan dan pengembangan-pengembangannya harus mempertimbangkan derajat kealamian dan karakter dari tempat dimana mereka berlokasi.

e. Keserasian antara kebutuhan wisatawan, tempat, dan penduduk sekitar harus dicari dan dipertemukan.

Menurut McIntyre (1993) dalam buku yang berjudul Sustainable Tourism Development Guide for Local Planner dinyatakan bahwa ada tiga komponen penting yang saling terkait dalam pengembangan sustainable tourism dan apabila ketiga komponen ini dilibatkan maka akan terjadi peningkatan kualitas hidup. Ketiga komponen yang dimaksud adalah:

a. Industri pariwisata

Industri pariwisata adalah dapat menciptakan lapangan pekerjaan, meningkatkan pendapatan, mendorong penanaman modal, meningkatkan kesempatan untuk mengembangkan bisnis. Dalam industri pariwisata yang dimaksud dengan penawaran adalah terdiri dari transportasi, atraksi wisata, fasilitas wisatawan, pelayanan dan semua yang berhubungan dengan infrastruktur, serta informasi dan promosi, industri pariwisata mencari lingkungan bisnis yang sehat dengan tersedianya jaminan keamanan, keuangan, tenaga kerja yang terlatih dan bertanggung jawab, atraksi yang berkualitas sehingga dapat mendatangkan wisatawan yang terus menerus.

b. Lingkungan

Agar kepariwisataan dapat bertahan lama maka tipe dan tingkat aktivitas kepariwisataan harus diseimbangkan dengan kapasitas tersedianya sumber daya, baik alam maupun buatan. Carrying capacity adalah hal yang mendasar dalam perlindungan dan pengembangan kepariwisataan bertahan lama. Konsep ini mengacu pada penggunaan secara maksimal terhadap sumber daya yang tersedia tanpa menyebabkan dampak negatif terhadap sumber-sumber daya tersebut, tanpa mengurangi kepuasan wisatawan, atau tanpa menambah masalah sosial, ekonomi, 
dan budaya di area obyek wisata tersebut. Tiga aspek dari lingkungan kepariwisataan, adalah : (a) Ecological, yaitu berhubungan dengan lingkungan alam, (b) Sociocultural, yang berhubungan dengan dampak terhadap kehidupan masyarakat dan kebudayaannya, (c) Facility, yang berhubungan dengan pengalaman pengunjung. Dalam mengembangkan kepariwisataan bertahan lama, sangat penting mempertimbangkan pemeliharaan kualitas lingkungan hidup dan kepuasan pengunjung seperti yang ditekankan sebelumnya, jika produk kepariwisataan merosot dalam kualitas, maka secara pasti akan terjadi kemerosotan ekonomi pariwisata.

c. Masyarakat

Pengembangan kepariwisataan memerlukan perubahan yang berhubungan dengan pemeliharaan, maka perlu bagi masyarakat sekitarnya untuk memperoleh keuntungan dan kepariwisataan yang dapat memuaskan mereka sehingga mereka mempunyai motivasi untuk mengadakan perubahan tersebut. Peningkatan taraf hidup masyarakat adalah faktor pokok. Keinginan masyarakat untuk terlibat adalah merupakan kunci untuk mengadakan perubahan yang akan meningkatkan kualitas hidup. Jika masyarakat terlibat dalam berbagai tahap maka masyarakat akan merasa termotivasi dan bertanggung jawab. Para tertua dan orang-orang kuno memerlukan perhatian khusus, karena mereka sulit untuk menerima perubahan-perubahan. Sejak awal sebaiknya masyarakat diberikan pengertian mengenai kepariwisataan dan dampak-dampak yang mungkin terjadi, sehingga nantinya tidak akan terjadi kesalahpahaman. Keuntungan yang dapat dicapai oleh masyarakat adalah tersedianya lapangan pekerjaan baru dan pendapatan tambahan, menciptakan kesempatan penanaman modal baru, memperbaiki fasilitas untuk pelayanan termasuk perairan, jalan, balai kesehatan, keamanan, serta infrastruktur yang lainnya, meningkatkan pangsa pasar untuk memasarkan produk lokal, memperbaiki kesempatan untuk tenaga kerja terlatih, memperbaiki fasilitas dan aktivitas rekreasi dan budaya yang juga bisa dinikmati oleh penduduk, dan peningkatan penghargaan terhadap kehidupan sosial masyarakat. Pihak yang merencanakan pengembangan harus mengikutsertakan masyarakat sejak awal tahap perencanaan.

\section{MOTODE PENELITIAN}

Pendekatan yang digunakan pada penelitian ini adalah pendekatan survei yang akan membantu untuk mendapatkan gambaran menyeluruh meliputi kondisi fisik, keadaan pariwisata serta situasi sosial dan budaya di DTW Ceking Desa Pekraman Tegallalang. Berdasarkan masalahnya, maka penelitian bersifat deskripsi fenomena pariwisata dan hubungannya dengan kehidupan sosial budaya serta lingkungan. Yang dijadikan responden dalam penelitian ini, antara lain pengurus Desa Pakraman setempat, pedagang, pedagang kaki lima, petugas keamanan, masyarakat setempat pemilik home stay atau bungalow dan sebagainya.

\section{A. Pengelolaan DTW Ceking}

\section{HASIL PENELITIAN DAN PEMBAHASAN}

Pengelolaan berarti proses, cara, perbuatan pengelola, proses melakukan kegiatan tertentu dengan menggerakkan tenaga orang lain, proses yang membantu merumuskan kebijaksanaan dan tujuan organisasi, proses yang memberikan 
pengawasan pada semua hal yang terlibat dalam pelaksanaan kebijakan dan pencapaian tujuan (Kamus Besar Bahasa Indonesia, 2005).

Menurut Darsoprajitno (2005) Pengelolaan dan manajemen memang berbeda, tetapi perbedaan tersebut tidak mudah diuraikan, sehingga seolah-olah mengelola dan manajemen tidak berbeda. Mengelola pengertiannya lebih dekat kepada mengendalikan atau menyelenggarakan, sedangkan manajemen yaitu runtunan pemanfaatan berbagai sumber daya secara berhasilguna untuk mencapai sasaran. Pengetahuan dan teknologi pengelolaan amat diperlukan untuk menjamin kesinambungan kegiatan kerja, termasuk bagaimana mengembangkannya sesuai dengan mantra waktu, ruang, dan prilaku budaya manusianya baik pengelola maupun para wisatawan yang datang berwisata. Demikian pula bagaimana teknologi pengelolaan antara wisatawan yang datang dengan objek dan daya tarik wisata yang dinikmatinya. Pengelolaan umumnya dikaitkan dengan aktivitas perencanaan, pengorganisasian, pengendalian, penempatan, pengarahan, pemotivasian dan pengambilan keputusan yang dilakukan oleh setiap organisasi dengan tujuan untuk mengkoordinasikan berbagai sumber daya yang dimiliki organisasi sehingga akan dihasilkan suatu produk atau jasa secara efisien.

Beberapa model pengelolaan dalam pengembangan pariwisata Bali Tengah antara lain:1.Pengelolaan oleh desa adat. Desa adat sebagai pengelola utama, sedangkan pemerintah, pelaku pariwisata, dan warga subak sebagai mitra dalam pengelolaannya; 2.Pengelolaan oleh subak. Model ini mengetengahkan masyarakat yang terlibat langsung dalam subak yang mengelola dalam usaha memberdayakan masyarakat, sedangkan pemerintah, pelaku pariwisata dan adat sebagai mitra subak dalam pengelolaannya; 3.Pengelolaannya adalah pelaku pariwisata yang lebih banyak mengetahui tentang kepariwisataan, sedangkan masyarakat, pemerintah merupakan mitra kerjanya; 4.Pengelolaan oleh pemerintah. Pengelolaan ini biasanya dilakukan dengan atau melalui badan usaha milik pemerintah. 5.Pengelolaan oleh subak dan adat dilakukan secara bersama-sama sedangkan pemerintah dan pelaku pariwisata sebagai mitra subak dan adat; 6.Pengelolaan oleh badan pengelola. Model ini menawarkan konsep keterpaduan antara unsur-unsur yang terlibat dalam obyek wisata, seperti desa adat, subak, pemerintah dan pelaku pariwisata secara bersama-sama mengelola sesuai peran masing-masing yang telah disepakati bersama. Pujaastawa, dkk (2005).

Pengelolaan yang dimaksud dalam penelitian ini adalah pengelolaan daya tarik wisata Ceking yang dikelola oleh desa adat sebagai pengelola utama, sedangkan pemerintah, pelaku pariwisata dan warga subak sebagai mitra pengelolaannya. Desa adat Ceking yang mendapat kepercayaan dari Pemkab Gianyar untuk mengelola objek wisata itu sejak 10 Maret 2012 mulai menata tempat parkir, toko maupun arus lalu lintas. Sesuai kesepakatan pendapatan objek wisata itu penggunaannya diarahkan untuk biaya operasional 32,34 persen, iuran ke Desa Pakraman Tegallalang 35 persen, investasi 30 persen dan Askes 2,66 persen. Salah satu Badan Pengelola DTW Ceking Dewa Putu Raka Selangga, mengatakan:

"Objek wisata yang dikelola desa pekraman (adat) Tegallalang itu cukup ramai dikunjungi wisatawan dalam dan luar negeri yang setiap bulannya mampu menghasilkan lebih dari Rp100 juta yang bersumber dari retribusi karcis masuk dan parkir, tutur Bendahara pengelola objek wisata tersebut, Dewa Putu Raka Selangga. Kedatangan wisatawan secara rombongan besar, kecil dan perorangan itu membawa dampak positif bagi masyarakat 
setempat, untuk berjualan dengan membangun toko kerajinan industri kecil serta rumah makan di sepanjang jalan objek wisata Ceking, Tegallalang” Namun dalam penataan dan pengembangan DTW Ceking menghadapi beberapa kendala antara lain banyaknya bus pariwisata ukuran besar tidak tertampung di tempat parkir sehingga menyebabkan kemacetan lalu lintas di daerah itu. Oleh sebab itu perlu memperluas tempat parkir dengan cara menyewa lahan masyarakat yang ada di sekitarnya. Seperti yang diungkapkan oleh salah satu pemilik sawah di area DTW Ceking, I Made Sutha, yang mengatakan :

"Meskipun penghasilan objek wisata Ceking cukup besar setiap bulannya, namun pemilik lahan sawah berterasering yang menjadi daya tarik objek wisata kami sebagi pemilik sawah sebanyak 14 orang hanya mendapat imbalan sangat murah. Saya mengharapkan pemerintah atau desa adat bisa membantu para petani, khususnya yang ada di wilayah Ceking dengan meningkatkan dana sumbangan pemeliharaan"

Menanggapi keluhan itu Kepala Dinas Kebudayaan Kabupaten Gianyar, Cokorda Gde Rai Widiarsa P mengatakan:

"Pemerintah Kabupaten (Pemkab) Gianyar bisa membantu para petani di Objek Ceking, jika sudah terdafatar dalam sebuah organisasi subuk. Hingga saat ini ke-14 petani pemilik lahan di ceking belum terdaftar dalam subak, sehingga kesulitan untuk mendapatkan bantuan dari pemerintah, baik dari Provinsi Bali maupun Pemkab Gianyar"

Lebih lanjut Guru besar Universitas Udayana Prof Dr I Wayan Windia memberikan solusi Pemkab Gianyar sebaiknya mengabulkan usulan petani di kawasan Ceking untuk menjadi sebuah subak. Dengan demikian petani akan dapat menyatukan dirinya untuk mengelola kawasan teras sawah di Ceking. Hal itu sudah dimohonkan oleh kelompok petani di Ceking. Prof Windia yang juga Ketua Pusat Penelitian (Puslit) Sistem Subak Unud juga menegaskan Jika petani di Ceking itu sampai putusasa dan melakukan tindakan boikot, bisa mengakibatkan ribuan warga yang hidup di kawasan Ceking dari jasa pariwisata akan mengalami kerugian. Hal ini cukup beralasan mengingat tuntutan petani di kawasan Ceking dikukuhkan menjadi subak adalah untuk mendapatkan bantuan hibah dari Pemprov Bali sebesar Rp20 juta per tahun. Oleh sebab itu kepentingan petani yang kondisi ekonominya kurang mampu harus difasilitasi, mengingat petani di kawasan Ceking memberikan manfaat yang besar kepada wisatawan dan kehidupan ekonomi penduduk setempat. Dengan demikian wajar jika tuntutan petani di kawasan Ceking, Tegallalang, Kabupaten Gianyar mendapat perhatian secara serius dari Pemkab Gianyar dan Pemprov Bali. Hal itu penting dilakukan, mengingat sistem subak yang diterapkan petani Bali menjadi komponen yang strategis dalam mendukung pembangunan sektor pertanian maupun pengembangan sektor pariwisata di Pulau Dewata. Demikian pula kebudayaan Bali, khususnya konsep "Tri Hita Karana" menjadi penghubung terhadap ketiga elemen, bahkan sistem subak menjadi landasan pokok bagi berkembangnya pertanian dan pariwisata. Jika sistem subak di Bali hancur, akan berpengaruh terhadap rusaknya kebudayaan, sekaligus sektor pertanian akan berantakan, yang segera disusul dengan kehancuran sektor pariwisata. Selanjutnya dijelaskan oleh Prof.Windia bahwa wisatawan mancanegara dalam menikmati liburan ke Bali semakin tertarik terhadap keberadaan sektor pertanian yang 
didukung oleh sistem pengairan tradisional dalam bidang pertanian yang lumrah dikenal dengan sistem subak. Kondisi sawah yang demikian masih bisa ditemui secara mudah di berbagai lokasi di Bali, meskipun secara fisik sejumlah subak di tempat-tempat strategis, khususnya di Kota Denpasar, Badung, dan Kabupaten Gianyar mulai beralih fungsi ke non-pertanian. Lahan pertanian yang beralih fungsi untuk berbagai lokasi pembangunan, termasuk sektor pariwisata setiap tahunnya tidak kurang dari 1.000 hektare dalam kurun waktu lima tahun terakhir dan sebelumnya rata-rata 750 hektare. Di balik alih fungsi lahan yang didukung sistem pengairan tradisional bidang pertanian (subak) di Pulau Dewata masih ada alam dan potensi budaya yang bisa dikembangkan lebih intensifkan menjadi atraksi wisata yang unik dan menarik, sebagai upaya meningkatkan kunjungan turis, meskipun wisman sudah berulang kali ke daeah ini. Namun pengembangan objek wisata alternatif itu memerlukan sentuhan kreativitas dan terobosan baru, sehingga kehadirannya bisa menarik dari objek yang ada selama ini. Lebih lanjut dijelaskan bahwa pengembangan objek wisata alternatif itu tetap berbasis pada budaya local yakni Sawah dan petani menjadi salah satu aset pariwisata. Dari kehidupan pertanian lahir nilai-nilai budaya agraris yang sangat luhur yang dapat dijadikan aset pariwisata. Sistem subak yang diwarisi secara turun temurun di Bali juga menjadi penyangga kebudayaan Bali, sekaligus salah satu daya tarik wisatawan khususnya DTW Ceking, tidak kalah dengan objek wisata buatan baru yang menanam investasi triliun rupiah ( Windia

\section{B. Pemberdayaan DTW Ceking}

Menurut Payne (dalam Pitana, 2011), pemberdayaan adalah proses untuk membantu masyarakat mendapatkan daya, kekuatan, atau kemampuan untuk mengambil keputusan dan tindakan, termasuk mengurangi kendala pribadi dan sosial di dalam mengambil keputusan dan tindakan tersebut.

Konsep pemberdayaan muncul sebagai usaha untuk memberikan masyarakat lokal atau masyarakat marginal agar terlepas dari ketidakmampuan bersuara (voicelessness) dan ketidakberdayaan (powerlessness) (Pitana, 2011).

Menurut World Bank 2002 (Pitana, 2011), pemberdayaan pada dasarnya berisikan empat elemen pokok yaitu: 1)Access to information (akses terhadap komunikasi), karena informasi adalah modal dalam pengembangan kemandirian; 2) Inclusion/

participation(penyertaan/partisipasi), yaitu kesempatan berparitisipasi dalam pembangunan pariwisata baik dalam proses perencanaan, pelaksanaaan maupun pemanfaatan hasilnya sangat penting bagi masyarakat lokal; 3).Accountability (akuntabilitas). Akuntabilitas berbagai pihak sangat diperlukan, termasuk dalam pengembangan kebijakan, pelaksanaan di lapangan, maupun pemanfaatan sumber daya termasuk dana; dan 4) Local organizational capacity (kapasitas organisasi lokal). Proses pemberdayaan masyarakat harus berisikan peningkatan kemampuan masyarakat untuk bekerjasama, mengembangkan dan memperkuat organisasi lokal, serta memobilisasi sumber daya untuk mengatasi berbagai permasalahan yang merupakan kepentingan bersama. 5) Bentuk pariwisata yang dapat memberikan manfaat bagi penduduk setempat adalah pariwisata berbasis kerakyatan (community based tourism). Pariwisata ini bertumpu pada kekuatan rakyat. Pitana (2002) menyatakan bahwa pembangunan pariwisata kerakyatan memiliki beberapa karakteristik ideal yaitu usaha yang dikembangkan 
berskala kecil, pemilikan dan pengelolaan dilakukan oleh masyarakat lokal (locally owned and managed). Sesuai dengan skalanya yang kecil dan pengelolaanya oleh masyarakat lokal, maka sebagian besar input yang digunakan baik pada saat konstruksi maupun operasi berasal dari daerah setempat. Aktivitas berantai (spinoff activity) yang ditimbulkan banyak, dengan adanya keterlibatan masyarakat lokal baik secara individual maupun kelembagaan, menjadi semakin besar. Adanya aktivitas berantai tersebut memberikan manfaat langsung yang lebih besar bagi masyarakat lokal. Berbasiskan kebudayaan lokal, karena pelakunya adalah masyarakat lokal. Pengembangan ramah lingkungan, yang tidak terkait dengan adanya konversi lahan secara besar-besaran serta tidak adanya perubahan bentuk bentang alam yang berarti. Melekatnya kearifan lokal (local wisdom) karena bercirikan keunikan daerah setempat. Penyebarannya tidak terkonsentrasi pada suatu kawasan, tetapi dapat menyebar ke berbagai daerah. Jadi, dapat disimpulkan bahwa pendekatan pembangunan berbasis kerakyatan akan lebih memberdayakan dan menguntungkan rakyat banyak, meningkatkan kualitas kehidupan masyarakat, sehingga keseimbangan dan keberlanjutan potensi atau modal dasar kepariwisataan di daerah tersebut akan tetap terjaga dan terpelihara Pitana (1999 ) melihat pembangunan pariwisata kerakyatan berbeda dengan pariwisata konvensional. Pembangunan ini lebih dikenal dengan model bottom up, pembangunan sebagai social learning menuntut adanya partisipasi masyarakat lokal dalam pembangunan dan pengelolaannya. Paturusi (2008) menyatakan karakteristik kepariwisataan berbasis masyarakat yakni: 1) Berskala kecil; 2) Dimiliki oleh anggota/kelompok masyarakat setempat, sehingga memberi manfaat bagi masyarakat setempat; 3)Memberikan kesempatan kerja dan peluang ekonomi pada ekonomi setempat; 4) Lokasinya tersebar tidak terkonsentrasi di suatu tempat; 5) Desain dan kegiatan mencerminkan karakter wilayah setempat; 6)Mengedepankan kelestarian wawasan budaya; 7) Tidak mematikan industri dan kegiatan lainnya saling melengkapi; 8) Menawarkan pengalaman yang berkualitas bagi wisatawan

9) Merupakan kegiatan usaha yang menguntungkan.

Menurut Korten (dalam Pujaastawa, 2002) menyatakan tiga alasan dasar mengenai pentingnya community management dalam pembangunan. Pertama, adanya local variety (variasi lokal) yang tidak dapat diberikan perlakuan sama, di mana situasi daerah yang berbeda menutut sistem pengelolaan yang berbeda sehingga masyarakat lokal yang paling memahami situasi daerahnya. Kedua, adanya local resources (sumber daya lokal) yang secara tradisional telah dikelola oleh masyarakat setempat dari generasi ke generasi, pengambilan pengelolaan akan menimbulkan ketersinggungan bila tidak melibatkanya. Ketiga, adanya local accountability (tanggungjawab lokal) yang berarti bahwa pengelolaan yang dilakukan oleh masyarakat setempat biasanya lebih bertanggung jawab, karena berbagai hal yang dilakukan terhadap sumber daya akan berpengaruh langsung terhadap mereka.

Masyarakat setempat harus mengawasi atau mengontrol pembangunan pariwisata dengan ikut terlibat dalam menentukan visi pariwisata, mengidentifikasi sumber-sumber daya yang akan dipelihara dan ditingkatkan, serta mengembangkan tujuan-tujuan dan strategi untuk pengembangan dan pengelolaan daya tarik wisata. Masyarakat juga harus berpartisipasi dalam mengimplementasikan strategi yang telah disusun sebelumnya. 
Partisipasi masyarakat dalam pembangunan pariwisata diartikan sebagai keterlibatan secara aktif dalam setiap proses pengembangan dari industri pariwisata, yaitu mulai dari perencanaan, penentuan rancangan, pelaksanaan, sampai dengan pengawasan dan pengevaluasian, dan penikmatan hasilnya (Pitana, 1999). Keterlibatan masyarakat dalam proses tersebut menjadi kontrol yang sangat efektif dan menjamin pengembangan suatu obyek wisata sesuai dengan perencanaan. Pengaturan ketentuan tentang daya tampung suatu obyek wisata harus dilaksanakan dengan musyawarah yang melibatkan masyarakat lokal dan tidak berdasarkan atas kepentingan seseorang atau golongan.

Pemberdayaan masyarakat dalam pengelolaan dan pengembangan yang dimaksud dalam penelitian ini adalah proses untuk membantu masyarakat Desa Tegallalang dan Desa Kedisan mendapatkan daya, kekuatan, atau kemampuan untuk mengambil keputusan dan tindakan, termasuk mengurangi kendala pribadi dan sosial di dalam mengambil keputusan dan tindakan dalam pengembangan dan pengelolaan daya tarik wisata Ceking. Masyarakat Desa Kedisan selaku pemilik lahan atau sawah yang menjadi daya tarik wisata Ceking sudah diberikan dana retribusi oleh pihak pengelola (BPOWC ) kepada pemilik lahan agar selalu menjaga lahannya tetap asri dan indah. Selain itu pengelola juga memperkejakan 14 orang petugas kebersihan di daya tarik wisata rice terrace Ceking. Berdasarkan Manajemen Sumber Daya Manusia, semua orang yang menjadi bagian dari Badan Pengelola Objek Wisata Ceking rice terrace berasal dari desa pekraman Tegallalang, mulai dari tim pengelola dan 14 orang karyawan yang di ambil masing-masing 2 orang dari 7 banjar yang ada di desa pekraman Tegallalang. Sedangkan dari Manajemen Keuangan, terdapat laporan harian, bulanan,dan tahunan. Semua laporan itu akan dikumpulkan oleh karyawan yang bertugas dan akan dilaporkan ke pihak pengelola sebulan sekali. Sementara ini pihak pengelola juga tidak menggunakan jasa auditor dalam mengaudit laporan keuangan, akan tetapi kedepannya setelah mengangkat tenaga ahli atau manager akan diupayakan menggunakan jasa auditor agar pengelolaan ini lebih professional.

\section{Daya Tarik DTW Ceking}

Undang-Undang RI Nomor 10 Tahun 2009 tentang Kepariwisataan menyebutkan bahwa daya tarik wisata adalah segala sesuatu yang memiliki keunikan, keindahan, dan nilai yang berupa keanekaragaman kekayaan alam, budaya, dan hasil buatan manusia yang menjadi sasaran atau tujuan kunjungan wisatawan.

Menurut Yoeti (1996), suatu daerah tujuan wisata hendaknya memenuhi beberapa syarat, yaitu:

a. Ketersediaan sesuatu yang dapat dilihat (something to see). Artinya, di tempat tersebut harus ada daya tarik yang berbeda dengan apa dimiliki daerah lain.

b. Sesuatu yang dapat dilakukan (something to do). Artinya, di tempat tersebut selain banyaki yang dapat dilihat dan disaksikan, harus pula disediakan fasilitas rekreasi yang dapat membuat mereka betah tinggal lebih lama di tempat itu.

c. Sesuatu yang dapat dibeli (something to buy). Artinya, di tempat tersebut harus tersedia fasilitas untuk berbelanja terutama barang-barang souvenir 
dan kerajinan rakyat sebagai oleh-oleh untuk dibawa pulang ke tempat asal masing- masing.

Menurut Yoeti (2006), secara garis besar terdapat empat kelompok yang merupakan daya tarik bagi wisatawan datang pada suatu negara daerah tujuan wisata tertentu, yaitu: natural attraction, build attraction, cultural attraction, dan social attraction.

a. Natural Attraction, termasuk dalam kelompok ini adalah pemandangan alam, laut, pantai, danau, air terjun, kebun raya, agrowisata, gunung berapi, serta flora dan fauna.

b. Build Attraction, termasuk dalam kelompok ini adalah bangunan dengan arsitektur yang menarik, seperti rumah adat, bangunan kuno dan bangunan modern.

c. Cultural Attraction, dalam kelompok ini termasuk diantaranya peninggalan sejarah (historical building), cerita-cerita rakyat (folklore), kesenian tradisional, museum, upacara keagamaan, festival kesenian dan semacamnya.

d. Social Attraction, yang termasuk kelompok ini adalah tata cara hidup suatu masyarakat (the way of life), ragam bahasa (languages), upacara perkawinan, upacara potong gigi, khitanan dan kegiatan sosial lainnya.

Wisatawan yang melakukan perjalanan wisata ke daerah tujuan wisata memerlukan berbagai kebutuhan dan pelayanan mulai dari keberangkatan sampai kembali lagi ke tempat tinggalnya. Aktivitas pariwisata sangat terkait dengan kehidupan kita sehari-hari. Sama seperti yang dilakukan setiap hari, wisatawan juga membutuhkan makanan dan minuman, tempat menginap, serta alat transportasi yang membawanya pergi dari suatu tempat ke tempat lainnya. Menurut Cooper dalam Suwena (2010), untuk memenuhi kebutuhan dan pelayanan tersebut, daerah tujuan wisata harus didukung empat komponen utama atau yang dikenal dengan istilah "4A" yaitu: Attraction (atraksi), Accessibility (aksesibilitas), Amenities (fasilitas), dan Ancillary Services (pelayanan tambahan).

Daya tarik wisata yang dimaksud dalam penelitian ini adalah sawah berundak yang memiliki keunikan, keindahan, dan nilai yang berupa keanekaragaman kekayaan alam, budaya, dan hasil buatan manusia yang menjadi sasaran atau tujuan kunjungan wisatawan ke Desa Tegallalang. Ceking rice terrace merupakan salah satu daya tarik wisata yang memiliki keindahan alam sebagai daya tarik utama, berada di wilayah Desa Kedisan, Kecamatan Tegallalang Kabupaten Gianyar, Bali. Walaupun terletak di Desa Kedisan, daya tarik wisata ini dikelola oleh Desa Pakraman Tegallalang Kecamatan Tegallalang, karena keindahan pemandangan (view) daya tarik wisata ini lebih bagus dilihat oleh wisatawan dari pinggir jalan yang berada di Desa Pakraman Tegallalang. Terletak tidak jauh dari Ubud, daya tarik wisata ini banyak dikunjungi wisatawan sehingga potensi manfaat ekonominya bisa dinikmati pengelola (Yulianie 2015). Hamparan lahan sawah dengan lokasi yang berundag-undag atau bertingkat-tingkat dikitari lingkungan yang lestari menjadi salah satu daya tarik objek Wisata Ceking di kawasan Tegallalang, Kabupaten Gianyar, sekitar 45 km timur laut Denpasar. Panorama alam sawah yang bertingkat-tingkat itu hampir mirip dengan pemandangan sawah di kawasan Jatiluwih, Kabupaten Tabanan yang telah ditetapkan sebagai warisan 
budaya dunia. Objek wisata yang dikelola desa pekraman (adat) Tegallalang cukup ramai dikunjungi wisatawan dalam dan luar negeri yang setiap bulannya mampu menghasilkan lebih dari Rp100 juta yang bersumber dari retribusi karcis masuk dan parker ( Bendahara pengelola objek wisata tersebut, Dewa Putu Raka Selangga) . Kedatangan wisatawan secara rombongan besar, kecil dan perorangan itu membawa dampak positif bagi masyarakat setempat, untuk berjualan dengan membangun toko kerajinan industri kecil serta rumah makan di sepanjang jalan objek wisata Ceking, Tegallalang tersebut. Namun kehadiran bangunan-bangunan permanen itu belum ditata secara maksimal sehingga tampak kurang kurang beraturan, tidak sesuai dengan kondisi lingkungan yang asri dan lestari.

\section{Strategi Pengembangan DTW Ceking}

Dalam pengembangan pariwisata baik yang masih berupa potensi maupun yang berupa objek dan daya tarik wisata yang sudah ada harus sesuai dengan kriteria-kriteria pengembangan pariwisata. Menurut Grady dalam Suwantoro (2002:50), ada beberapa kriteria sebagai arahan yang lebih jelas dalam pengembangan pariwisata yaitu :

a. Decision making about the form of tourism in any place must be made in consultation with the local people and be acceptable to them.

b. A reasonable share of the profits derived from tourism must be return to the people.

c. Tourism must be based on sound environmental and ecological principles, be sensitive to local cultural and religious traditions and should not place any members of the host community in a position of inferiority.

d. The numbers of tourism visiting an area should not be such that they over shelm the local population and deny possibility of genuine human encounter.

Pengambilan keputusan mengenai bentuk pengembangan pariwisata di setiap tempat harus dilakukan dengan berkonsultasi dengan masyarakat lokal dan dapat diterima oleh masyarakat lokal tersebut. Hal ini dilakukan agar pengembangan pariwisata tersebut dapat berjalan dengan lancar, tidak mendapat halangan dari masyarakat lokal. Tanpa dukungan dari masyarakat lokal maka mustahil pengembangan pariwisata akan berjalan sesuai dengan yang direncanakan.

Sebagian keuntungan yang diperoleh dari pengembangan pariwisata akan diberikan kepada masyarakat lokal. Artinya, pengembangan pariwisata diharapkan dapat memberikan manfaat ekonomi bagi masyarakat lokal yang nantinya dapat dimanfaatkan untuk memenuhi kebutuhan hidupnya dan juga untuk menjaga kelestarian sumber daya yang ada.

Bentuk pariwisata yang dikembangkan tersebut harus didasarkan pada prinsip-prinsip lingkungan dan ekologis, peka terhadap tradisi budaya dan agama setempat dan tidak harus menempatkan setiap anggota masyarakat tuan rumah dalam posisi inferiory. Pariwisata dikembangkan sesuai dengan daya dukung lingkungan yang dimiliki agar tidak menmbulkan kerusakan lingkungan. Selain itu, kegiatan pariwisata yang dikembangkan menghargai tradisi budaya dan agama setempat agar tidak menimbulkan kesalahpahaman di antara pihak pengembang dan masyarakat lokal. Dalam pengembangan pariwisata, masyarakat lokal perlu 
dilibatkan dan setiap proses pengembangan. Keterlibatan ini tentunya disesuaikan dengan keahlian dan keterampilan sumber daya manusia yang ada di daerah tersebut.

Jumlah kunjungan wisatawan dalam suatu area tidak harus melebihi penduduk lokal dan menyangkal kemungkinan pertemuan dengan masyarakat asli setempat. Jumlah kunjungan wisatawan ke suatu area harus disesuaikan dengan daya dukung lingkungan, sehingga diperlukan batasan-batasan jumlah pengunjung agar tidak merusak lingkungan di sekitar area pariwisata. Bentuk pariwisata yang dikembangkan tidak membatasi interaksi antara wisatawan dan masyarakat lokal. Sehingga dengan demikian akan terjadi interaksi yang baik di antara kedua belah pihak.

Dapat disimpulkan pengembangan pariwisata yang dimaksud dalam penelitian ini adalah pengembangan pariwisata yang dapat diterima dan didukung oleh masyarakat lokal, dikembangkan berdasarkan prinsip-prinsip lingkungan dan ekologis, peka terhadap tradisi budaya dan agama setempat, serta dapat memberikan manfaat bagi masyarakat lokal khususnya masyarakat Desa Tegallalang dan Desa Kedisan. Strategi yang diterapkan oleh BPOWC dalam pengembangan DTW Ceking sejalan dengan penelitian yang dilakukan oleh Prananda (2018) mengungkapkan yakni: Pertama, langkah-langkah atau strategi umum yang perlu dilakukan untuk mewujudkan pariwisata berkelanjutan di daya tarik wisata Ceking rice terrace adalah strategi pertumbuhan melalui pengembangan produk dengan melakukan diferensiasi dan inovasi produk seperti membuat suatu produk atau paket pada saat musim menanam padi dimana wisatawan yang datang bisa merasakan pengalaman langsung bagaimana proses saat menanam padi dan membajak sawah sedangkan pada musim panen wisatawan bisa ditawarkan pengalaman bagaimana cara dan proses saat memanen padi hingga menjadi beras. Pengelola juga bisa menawarkan wisatawan untuk mempelajari tentang apa itu subak, dan juga kearifan lokal yang ada disana. Kedua, untuk mencapai strategi umum ada 9 strategi alternatif dengan skala prioritas yaitu Penanganan konflik, Evaluasi pemberian kompensasi, Penataan ulang lingkungan, Penerapan manajemen professional, Penangulangan Bencana, Meningkatkan Kualitas Pelayanan, Meningkatkan Pengawasan, Memanfaatkan Teknologi Informasi, Meningkatkan SDM. Berdasarkan kesimpulan yang disampaikan dapat diberikan saran sebagai berikut : Pertama, pengelola bisa membuat suatu produk atau paket pada saat musim menanam padi, pengelola juga bisa menawarkan wisatawan untuk mempelajari tentang apa itu subak, dan juga kearifan lokal yang ada disana. subak, organisasi yang ada, dan pendalaman local wisdom (kearifan lokal). Hal lain yang bisa ditawarkan oleh pengelola adalah cooking class menggunakan bahan-bahan dari hasil panen penduduk lokal disana, selain beras sebagai hasil panen utama, pengelola bisa mengajak wisatawan merasakan pengalaman berbelanja di pasar tradisional dengan menawar langsung kepada penjual bahan-bahan masakan yang akan dibuat nantinya pada saat cooking class. Sebagai tambahan lain mungkin pengelola bisa memberikan ijin untuk melakukan foto pra-wedding disekitar lokasi daya tarik wisata Ceking rice terrace. Akan tetapi sebelum kita menggunakan strategi pengembangan produk, alangkah baiknya pengelola mengutamakan strategi prioritas pengelolaan sesuai hasil penelitian. Kedua, pemerintah Kabupaten Gianyar melalui Dinas Pariwisata Daerah Kabupaten Gianyar hendaknya membantu pengelola melakukan pendekatan dengan pihak masyarakat lokal 
pemilik lahan sawah yang digunakan sebagai daya tarik wisata guna mencari solusi terbaik untuk menyelesaikan konflik yang terjadi agar pengelolaan daya tarik wisata Ceking rice terrace tidak terhambat karena adanya tuntutan dari pemilik lahan. Pemerintah Kabupaten Gianyar melalui Dinas Pekerjaan Umum dan Penataan Ruang hendaknya menindak dengan tegas para pemilik bangunan yang melanggar dan menghalangi pemandangan di sekitar daya tarik wisata Ceking rice terrace. Ketiga, saran untuk penelitian lebih lanjut. Oleh karena penelitian ini terbatas pada strategi pengelolaan di Ceking rice terrace, maka disarankan kepada penelitian berikutnya untuk lebih dalam mengkaji dari segi pengembangan daya tarik wisata potensial lainnya di Tegallalang, Gianyar sehingga potensi wisata tersebut bisa dikembangkan dan memberikan kontribusi positif kepada masyarakat untuk mewujudkan pariwisata yang berkelanjutan di Tegallalang Gianyar.

\section{E. Pariwisata Berkelanjutan di DTW Ceking}

Konsep pembangunan pariwisata berkelanjutan berawal dari konsep pembangunan berkelanjutan. Pembangunan berkelanjutan diharapkan akan memberi kesempatan pada generasi berikutnya untuk menikmati manfaat positif pembangunan, begitu juga dalam pembangunan pariwisata. (Swarbrooke,1999), menyatakan

"from of tourism which meet the needs of tourist, the tourist industry, and the host communities today without compromising the ability of future generations to meet their own needs “

Pariwisata dikembangkan untuk memenuhi kebutuhan wisatawan, industri pariwisata dan kebutuhan masyarakat lokal saat ini tanpa mengorbankan kemampuan generasi yang akan datang untuk memenuhi kebutuhannya sendiri. Artinya, pengembangan pariwisata diharapkan dapat memberikan manfaat secara berkelanjutan bagi masyarakat lokal saai ini dan generasi berikutnya.

Pembangunan pariwisata berkelanjutan didasarkan pada beberapa prinsip seperti yang dikemukakan United Nations World Tourism Organization (UNWTO, 2008:8) yaitu: 1) Semua pemangku kepentingan pembangunan kepariwisataan harus menjaga lingkungan hidup; 2) Pemerintah mendorong semua bentuk pembangunan kepariwisataan yang dapat mengurangi penggunaan sumber daya yang langka; 3) Pengaturan perjalanan wisatawan dan pengunjung dari sisi waktu maupun ruang untuk memeratakan pembagian waktu liburan guna mengurangi tekanan terhadap lingkungan hidup; 4) Infrastruktur kepariwisataan harus dirancang dan kegiatan kepariwisataan harus diprogramkan sedemikian rupa untuk melindungi warisan alam; 5) Wisata alam atau wisata ekologi untuk menjaga warisan alam dan menghormati penduduk setempat serta tetap memperhatikan daya dukung tempat.

Jadi, pembangunan pariwisata berkelanjutan haruslah memanfaatkan sumber daya alam secara optimal sesuai daya dukung sehingga tidak menimbulkan kerusakan, menghormati sosial budaya masyarakat setempat dan memastikan manfaat ekonomi yang berkelanjutan dan terdistribusi secara adil pada seluruh stakeholders.

Pembangunan pariwisata berkelanjutan (sustainable tourism development) pembangunan pariwisata yang menekankan pada prinsip pembangunan 
berkelanjutan. WTO (1999), menekankan ada tiga hal penting dalam pembangunan pariwisata berkelanjutan yaitu quality, continuity, dan balance.

a. Quality. Sustainable tourism provides a quality experience for visitor, while improving the quality of the host community and protecting the quality of environment.

b. Continuity. Sustainable tourism ensures the continuity of the natural resources upon which it based and the continuity of the cultural of the host community with satisfying experience for visitors.

c. Balance. Sustainable tourism balances the need of the tourism industry, supporters of environment, and the local community.

Pariwisata berkelanjutan dikatakan berkualitas apabila dapat menyediakan sebuah pengalaman yang berkualitas bagi pengunjung, sementara itu juga dapat meningkatkan kualitas hidup masyarakat lokal dan melindungi kualitasn lingkungan. Pariwisata menjamin kelangsungan sumber daya alam dan budaya masyarakat lokal dengan pengalaman yang memuaskan bagi pengunjung. Pariwisata berkerlanjutan juga diharapkan dapat menjaga keseimbangan antara kebutuhan industri pariwisata, dukungan terhadap lingkungan dan masyarakat lokal. Jadi, prinsip quality, continuity, dan balance harus diterapkan dalam pengembangan pariwisata berkelanjutan.

Menurut Varesci (dalam Yoeti, 2008) menyebutkan dalam pembangunan pariwisata berkelanjutan harus meliputi:

a. Comprehensive approach, diperlukan adanya pendekatan menyeluruh didalam menentukan kebijakan yang akan diambil.

b. Integrated approach, pembangunan pariwisata harus terintegrasi, dimana pembangunan yang dilakukan di daerah (local) tidak bertentangan dengan pembangunan yang berskala nasional dan bahkan dengan kebijakan pembangunan pariwisata dalam ruang lingkup global.

c. Strategic approach, dalam melaksanakan pembangunan pariwisata untuk mencapai hasil yang maksimal diperlukan strategi yang ditetapkan berdasarkan pada suatu visi (sesuatu yang dicita-citakan) dan misi (cara pencapaiannya). Penetapan strategi oleh perencana akan memudahkan dalam pencapaian tujuan pembangunan.

Participatory approach, partisipasi masyarakat berhubungan dengan keterlibatan seluruh komponen dalam proses pengambilan keputusan (decision making) terhadap perencanaan yang akan dilakukan di kawasan yang akan ditingkatkan menjadi daerah tujuan wisata.

Pariwisata berkelanjutan yang dimaksud dalam penelitian ini adalah pariwisata yang memanfaatkan sumber daya alam secara optimal sesuai daya dukung sehingga tidak menimbulkan kerusakan, menghormati sosial budaya masyarakat setempat dan memastikan manfaat ekonomi yang berkelanjutan dan terdistribusi secara adil pada seluruh stakeholders yang ada di sekitar daya tarik wisata Ceking.

Konsep pariwisata berkelanjutan dari UNWTO (2005) yaitu keberlanjutan ekosistem, menghormati sosial budaya masyarakat dan memberikan manfaat ekonomi yang berkelanjutan kepada stakeholders atau pemangku kepentingan sangat cocok diterapkan di daya tarik wisata Ceking rice terrace, karena masalah 
yang terjadi dan terlihat sekarang sangat mengancam keberlanjutan aktifitas pariwisata di daya tarik wisata tersebut. Selain itu, menurut Sudiarta (2012) pelayanan prima merupakan hal penting dalam menunjang keberlanjutan pariwisata. Ke depannya apabila pengelola tidak memiliki rumusan strategi yang tepat, hal ini menjadi suatu masalah dalam pengelolaan dan pengembangannya sebagai daya tarik wisata untuk mewujudkan pariwisata berkelanjutan. Pengelolaan Ceking rice terrace sebagai daya tarik wisata adalah langkah-langkah atau program kerja yang telah dilaksanakan oleh pihak pengelola atau yang biasa disebut BPOWC selama ini dalam operasionalnya mewujudkan Ceking rice terrace sebagai daya tarik wisata. Berdasarkan Manajemen Sumber Daya Alam, pihak pengelola sudah melakukan upaya memberikan dana retribusi kepada pemilik lahan agar selalu menjaga lahannya tetap asri dan indah. Selain itu pengelola juga memperkejakan 14 orang petugas kebersihan di daya tarik wisata rice terrace Ceking. Berdasarkan Manajemen Sumber Daya Manusia, semua orang yang menjadi bagian dari Badan Pengelola Objek Wisata Ceking rice terrace berasal dari desa pekraman Tegallalang, mulai dari tim pengelola dan 14 orang karyawan yang di ambil masing-masing 2 orang dari 7 banjar yang ada di desa pekraman Tegallalang. Sedangkan dari Manajemen Keuangan, terdapat laporan harian, bulanan,dan tahunan. Semua laporan itu akan dikumpulkan oleh karyawan yang bertugas dan akan dilaporkan ke pihak pengelola sebulan sekali. Sementara ini pihak pengelola juga tidak menggunakan jasa auditor dalam mengaudit laporan keuangan, akan tetapi kedepannya setelah mengangkat tenaga ahli atau manager akan diupayakan menggunakan jasa auditor agar pengelolaan ini lebih profesional. Berdasarkan Manajemen Pemasaran, Badan Pengelola Objek Wisata Ceking atau BPOWC selama ini tidak mempunyai strategi khusus dalam mempromosikan daya tarik wisata Ceking rice terrace, karena mereka beranggapan daya tarik wisata Ceking Rice Terrace berada di jalur strategis dan sudah terkenal dari dulu sehingga tidak perlu promosi lagi. Kedepannya pihak pengelola atau BPOWC akan memaksimalkan peran seksi atau divisi Sosial Ekonomi dalam meningkatkan kunjungan wisatawan.

\section{F. Pariwisata Berbasis Kerakyatan Di DTW Ceking}

Dalam pengembangan pariwisata yang berbasiskan kerakyatan, kegiatan masyarakat berbaur dengan kegiatan pariwisata sehingga sumber daya alam, budaya, industri, kearifan-kearifan lokal, dan sumber daya lokal lainnya yang dimiliki oleh masyarakat lokal yang dijadikan sebagai obyek dan daya tarik pariwisata tetap terjaga kelestariannya dan masyarakat lokal mendapatkan keuntungan ekonomi yang digunakan untuk kesejasteraan hidupnya dan menjaga kelestarian sumberdaya tersebut. Hal tersebut sejalan dengan yang diungkapkan oleh Prof Windia (2012), yang menyatakan sebagai berikut:

“.........Pengembangan objek wisata alternatif itu tetap berbasis pada budaya local, seperti sawah dan petani yang terdapat di Tegallalang menjadi salah satu aset pariwisata. Dari kehidupan pertanian lahir nilainilai budaya agraris yang sangat luhur yang dapat dijadikan aset pariwisata. Sistem subak yang diwarisi secara turun temurun di Bali juga menjadi penyangga kebudayaan Bali, sekaligus salah satu daya tarik wisatawan, tidak kalah dengan objek wisata buatan baru yang menanam investasi triliun rupiah". 
Pariwisata berbasis kerakyatan menintikberatkan pada keseimbangan dan keharmonisan di antara lingkungan hidup, sumber daya alam dan sumber daya manusia serta pengunjung atau wisatawan yang dijiwai dengan pemanfaatan kearifan-kearifan lokal sebagai daya tarik wisatanya, memelihara agar lingkungan tetap lestari, mengkomsumsi hasil pertanian setempat serta mencintai budaya, adat istiadat masyarakat setempat. Partisipasi masyarakat dalam pembangunan pariwisata diartikan sebagai keterlibatan secara aktif dalam setiap proses pengembangan dari industri pariwisata, yaitu mulai dari perencanaan, penentuan rancangan, pelaksanaan, sampai dengan pengawasan dan pengevaluasian, dan penikmatan hasilnya (Pitana, 1999). Keterlibatan masyarakat dalam proses tersebut menjadi kontrol yang sangat efektif dan menjamin pengembangan suatu obyek wisata sesuai dengan perencanaan. Hal ini sejalan dengan yang diungkapkan oleh Perbekel Tegallalalang Dewa Rai Sutrisna yang mengatakan bahwa:

“......Pengelolaan objek wisata berbasis alam pertanian ini mutlak harus dijaga, dengan melibatkan seluruh lapisan masyarakat Desa Tegallalang”.

Bentuk pengembangan pariwisata berbasis kerakyatan memiliki keunggulan tersendiri seperti; penciptaan lapangan kerja yang lebih luas untuk masyarakat, pendukung pelestarian budaya, adanya keyakinan yang lebih menjamin bagi upaya pelestarian sumber daya masyarakat setempat, dan adanya keuntungan ekonomi yang secara langsung dinikmati oleh masyarakat. Hal ini sejalan seperti yang dipaparkan oleh Agus P (2019) tokoh muda Tegallalang seperti berikut:

“....Di balik alih fungsi lahan yang didukung sistem pengairan tradisional bidang pertanian (subak) di Pulau Dewata khususnya di kawasan wisata Ceking ini masih ada alam dan potensi budaya yang bisa dikembangkan lebih intensifkan menjadi atraksi wisata yang unik dan menarik, sebagai upaya meningkatkan kunjungan turis, meskipun wisman sudah berulang kali ke daeah ini".

Pengembangan pariwisata berbasis kerakyatan tidak hanya memiliki keunggulan, tetapi memiliki beberapa kelemahan juga, misalnya; masyarakat lokal tidak memiliki visi dan misi dalam perencanaan jangka panjang dan tidak memiliki cukup modal untuk membangun secara cepat. Ketidakmampuan masyarakat lokal untuk terlibat dalam kegiatan pariwisata yang disebabkan karena kurangnya pengetahuan dan keahlian dalam bidang pariwisata (Pitana, 1999).

Pariwisata berbasis kerakyatan yang dimaksud dalam penelitian ini adalah kegiatan pariwisata yang berbaur dengan kegiatan masyarakat sehingga sumber daya alam, budaya, industri, kearifan-kearifan lokal, dan sumber daya lokal lainnya yang dimiliki oleh masyarakat lokal yang dijadikan sebagai obyek dan daya tarik pariwisata yaitu daya tarik wisata Ceking tetap terjaga kelestariannya dan masyarakat lokal mendapatkan keuntungan ekonomi yang digunakan untuk kesejasteraan hidupnya dan menjaga kelestarian sumberdaya tersebut.

\section{KESIMPULAN}

Dalam pengembangan daya tarik wisata Ceking akan menimbulkan dampak baik positif maupun negatif. Dampak negatif yang ditimbulkan dari pengembangan tersebut harus bisa diminimalisasi sehingga tidak menimbulkan kerusakan bagi 
daya tarik tersebut. Dampak positif secara ekonomi dari pengembangan daya tarik wisata Ceking akan dinikmati oleh pemerintah, masyarakat (sebagai pengelola dan partisipan) dan pengusaha pariwisata. Dampak ekonomi ini sering menimbulkan konflik kepentingan akibat persaingan untuk memperoleh manfaat ekonomi yang lebih besar dari pengembangan tersebut. Komponen masyarakat dalam pengembangan dan pengelolaan daya tarik wisata Ceking secara umum adalah seluruh warga masyarakat Desa Tegallalang. Pengelolaan daya tarik wisata oleh masyarakat Desa Tegallalang melalui suatu lembaga pengelola telah menunjukkan peran masyarakat dalam pengembangan daya tarik Ceking. Keterlibatan masyarakat tersebut tentunya akan memperoleh manfaat ekonomi yang lebih banyak dari daya tarik wisata Ceking sehingga akan mendukung peningkatan kesejahteraan masyarakat Desa Tegallalang dan Desa Kedisan selaku pemilik lahan pertanian yang dijadikan daya tarik wisata Ceking. Kelompok petani pemilik lahan yang menjadi pemilik dari ssawah yang menjadi daya tarik utama Ceking perlu mendapat perhatian lebih dari BPOWC Ceking terutama dalam perolehan manfaat ekonomi dari pengembangan daya tarik wisata Ceking. Hal ini dikarenakan lahan pertanian sebagian besar terletak di wilayah Desa Kedisan dan petani pemilik lahan merupakan warga Desa Kedisan. Perhatian tersebut penting untuk menghindarkan kesan dan upaya menjadikannya sebagai objek tontonan belaka. Peningkatan perolehan manfaat ekonomi bagi masyarakat petani pada daya tarik Ceking akan meningkatkan rasa memiliki dan rasa ketergantungan dari keberadaan daya tarik tersebut bagi kehidupan mereka. Dengan demikian para petani pemilik lahan akan tetap beraktifitas dan menjaga lahan pertaniannya sebagai daya tarik utama wisata Ceking.

\section{Implikasi Penelitian}

Desa Pekraman Tegallalang melalui BPOWC sebagai pengelola obyek wisata Ceking agar lebih intensif mengatur ketertiban lalu lintas terutama bus-bus besar dan kendaraan roda empat pengangkut wisatawan yang mengunjungi DTW Ceking, serta melakukan pembinaan terhadap para pedagang souvenir yakni dengan lebih banyak menyediakan souvenir khas daerah Ceking serta memberikan pelayanan yang lebih baik kepada wisatawan.

Promosi obyek wisata DTW Ceking, masih perlu dioptimalkan dengan website, sehingga bisa efektif mengjangkau jaringan internasional. Mengoptimalkan pelayanan kepada wisatawan sangat penting untuk dilakukan untuk mendorong kunjungan ke obyek wisata DTW Ceking, sehingga dapat menimbulkan mindset wisatawan dalam membentuk pengalaman wisatawan setelah berkunjung ke obyek Ceking . Dengan demikian pelayanan kepada wisatawan harus selalu ditingkatkan sehingga wisatawan selalu merasa puas setelah berkunjung ke obyek wisata Ceking.

Disamping itu untuk membentuk image wisatawan terhadap obyek wisata Ceking yang sudah baik selama ini namun masih perlu ditingkatkan untuk pengelolaan yang terkait denagn faktor lingkungan yang nyaman, sejuk dan segar serta menyenangkan. Faktor kebersihan obyek wisata dan Keamanan wisatawan yang berkunjung masih perlu upaya penanganan yang lebih baik. Kebersihan obyek wisata perlu dijaga dengan menyediakan kotak-kotak tempat sampah yang lebih banyak lagi di tempat-tempat yang strategis yang ramai dikunjungi wisatawan disertai dengan semboyan : Ceking Clean And Green, sehingga memberi motivasi 
wisatawan yang berkunjung ikut berpartisipasi menjaga kebersihan obyek wisata DTW Ceking. Faktor keamanan perlu mendapat perhatian sehingga wisatawan yang berkunjung ke obyek ekowisata ini merasa aman, karena terlindungi oleh petugas keamanan yaitu polisi wisata, desa adat/pecalang serta guide lokal yang lebih mengenal obyek ekowisata Ceking dan terhindar dari resiko kecelakaan karena lalu lintas yang masih kurang tertib. Wisatawan yang merasa aman berkunjung ke obyek Wisata Ceking dan senantiasa dijaga kebersihan lingkungannya akan merupakan promosi word of mouth

\section{DAFTAR PUSTAKA}

Bater, J.et al. 2001. Sustainable Touism Development. Canadian Universities Consortium: Urban Environmental Management Project Training \& Technology Transfer Program, Canadian Internasional Development Agency (CIDA)

Black, James A. Dean J. Champion. 1999. Metode dan Masalah Sosial. Bandung: Refika Aditama

Burhanuddin. 2008. Pendekatan, Metode dan Teknik Penelitian Pendidikan. Purwakarta: UPI

Darmayudha, Suasthawa I M., I W. Koti Cantika. 1991. Filsafat Adat Bali. Denpasar: PT. Upada Sastra.

Dowling RK dan Fennell DA. 2003. The Context of Ecotou-rism Policy and Planning. Di dalam: Fennel DA dan Dowling RK (editor). Ecotourism Policy and Planning. Cambridge. CABI Publishing. Hal 1-20.

Handoko, Putut. 2007. Mediasi Konflik Penanganan Kerusakan Pantai (Studi Kasus Penanganan Abrasi Pantai Kuta Bali). Tesis. Semarang: Program Magister Ilmu Lingkungan Program Pascasarjana Universitas Diponegoro

Iskandar. 2009. Metodologi Penelitian Kualitatif. Jakarta: GP Press

Kabupaten Badung. 2014. Kecamatan Kuta. (serial online), Jun, [cited 2014 Jun. 21]. Available from: URL: http://www.badungkab.go.id/index2. php? option $=$ com-content\&do $\mathrm{pdf}=1 \& \mathrm{id}=107$.

Keraf, Gorys. 1997. Komposisi: Sebuah Pengantar Kemahiran Bahasa. EndeFlores: Penerbit Nusa Indah.

Leiper, neil. 1990. Tourism systems: An Interdisiciplinary Perspective. Department of Management Systems, Business Studies Faculty, Masey University, Palmerston North, New Zealand.

Manuaba, Adnyana. 2003. Permainan Uang Bisa Hancurkan Bali. Bali Post Online. Jun, [cited 2014 Jun. 21]. Available from: URL: http://www.balipost.co.id/balipostcetak/2003/4/29/o3.htm

Moleong, Lexy J. 1994. Metode Penelitian Kualitatif. Bandung: PT Remaja Rosdakarya.

Murphy, P.E. 1985. Tourism: A Community Approach. London: Methuen.

Nasution, S. 2007. Metode Research. Jakarta: Bumi Aksara.

Nazir, M. 1990. Metode Penelitian. Jakarta: Ghalia Indonesia

Pantiyasa, Wayan. 2011. Pengembangan Pariwisata Berbasis Masyarakat (Community Based Tourism) dalam Pemberdayaan masyarakat (Studi Kasus di Desa Bedulu, Blahbatuh, Gianyar). Jurnal Ilmiah Hospitality Management. Vol. 1. No. 2. Hal: 38-73 
Putera, Prakoso Bhairawa. 2010. Penerapan Destination Management System (DMS) dalam Pemasaran Pariwisata Berbasis Teknologi Informasi dan Komunikasi (TIK). (serial online), Mar, [cited 2014 Mar. 20]. Available from: URL: http://wawaydisdik.blogspot.com/2010/03/penerapandestination-management-system.html

Sharpley, Richard. 2000. Tourism and Sustainable Development: Exploring the Theoretical Divice. Journal Of Sustainable Tourism, Vol. VIII (1). Hal 119.

Suansri, Potjana. 2003. Community-Based Tourism Handbook. Thailand: REST Project.

Sucipta, Abdi. 2010. Strategi Pengembangan Ekowisata Desa Blimbing Kecamatan Pupuan Kabupaten Tabanan. (serial online), Mar, [cited 2014 Mar. 20]. Available from: URL: www.pps.unud.ac.id/.../unud-278108584358-babii.pdf

Sukarma. 2007. Menjadi Generasi Pembelajar: Memahami Eksistensi Sekaa Teruna. Dalam Buletin Sabha Yowana Bali.

Susilo, Edi. 2010. Dinamika Struktur Sosial Dalam Ekosistem Pesisir. Malang: Universitas Brawijaya Press.

UNCTAD. 2005. E-tourism in developing countries: more links, fewer leaks. Linking Economies. Issue In Brief, Number 6.

Wirawan, Surya, 2009. Pengembangan Daya Tarik Wisata Bahari Secara Berkelanjutan Di Nusa Lembongan Kabupaten Klungkung. (serial online), [cited 2014 Mei. 1]. Available from: URL: www.pps.unud.ac.id/.../unud278-108584358-babii.pdf. 